\title{
Formulation and evaluation of a mucoadhesive buccal tablet of mefenamic acid
}

\author{
Karen Lu Li ${ }^{1,2}$ *, Agnes Llamasares Castillo ${ }^{(1,2,3}$ \\ ${ }^{1}$ The Graduate School, University of Santo Tomas, Manila, Philippines, ${ }^{2}$ Faculty of \\ Pharmacy, University of Santo Tomas, Manila, Philippines, ${ }^{3}$ Research Center for the \\ Natural and Applied Sciences, University of Santo Tomas, Manila, Philippines
}

\begin{abstract}
Buccal route of administration has many advantages such as improving patient compliance, bypassing the GIT and hepatic first pass effect. The objectives are to formulate mucoadhesive buccal tablet using Mefenamic acid and compatible excipients, and to evaluate the product using quality control tests and in vitro tests. The ingredients were subjected to Differential Scanning Calorimetry and Fourier Transform Infrared Spectroscopy studies for compatibility test and the results showed no interaction. Two batches of mefenamic buccal tablet were prepared. The tablet thickness and diameter are 3.75 $\mathrm{mm}$ and $12 \mathrm{~mm}$ respectively. All tablets are within the specification of $+/-5 \%$. The in-house tablet hardness is $6.8-15 \mathrm{~kg}$ and percent friabilation is not more than $0.8 \%$. The disintegration test showed that all tablets disintegrated within 4 hours. The content uniformity showed that tablets are within the range of $85 \%-115 \%$. The tablet weight is within the $5 \%$ range. The percent swelling is $53.83 \%$ to $58.86 \%$ and moisture absorption is $14.79 \%$ to $15.56 \%$. The surface $\mathrm{pH}$ of the tablet is close to the salivary $\mathrm{pH}$, which means that it would not irritate the buccal mucosa. The buccal tablet has a mucoadhesiveness of 0.196 to 0.200 . There was no change in $\mathrm{pH}$ and size after subjecting it to stability studies in human saliva. Drug release studies showed $80.7 \%$ to $83.4 \%$ after 3 hours. Even after 3 months of subjecting the tablets to $40{ }^{\circ} \mathrm{C}$ and $75 \% \mathrm{RH}$, results are within acceptable range. The results show the potential of the formulation as a mucoadhesive buccal tablet.
\end{abstract}

Keywords: Mefenamic acid. Buccal tablet. Mucoadhesive. Drug Release. HPMC K4M. SCMC.

\section{INTRODUCTION}

The oral route of drug administration is the most suitable route and widely accepted by patients and healthcare professionals for the delivery of therapeutically active drugs (Velmurugan, Srinivas, 2013). Advantages of oral route of administration include convenience, cost-effectiveness, drug stability, and accurate dosage. Despite its advantages, hepatic first pass metabolism, which is the elimination of drug by the liver before reaching the systemic circulation, and enzyme degradation within the gastrointestinal tract (GIT),

*Correspondence: K. Li, The Graduate School, University of Santo Tomas, España, Manila 1015, Philippines. E-mail: karenluli1993@gmail.com serves as limiting factors for its use (Le, 2016; Shepherd, 2011; Velmurugan, Srinivas, 2013). Throughout the years, researchers in the advancement of drug studies are concentrating on other routes of administration to enhance pharmaceutical products, and to overcome the limitations of the oral route of administration. Buccal route of administration is a good alternative to the oral route due to its advantages in overcoming problems associated with oral administration. It has the advantage of avoiding the gastrointestinal tract (GIT), hepatic first pass effect and drug degradation in the GIT environment (Chinna, Chaitanya, Madhusudan, 2011; Velmurugan, Srinivas, 2013). The buccal route is useful for both local and systemic effect (Gilhotra et al., 2014). The disadvantages of buccal route include low permeability 
of buccal membrane as compared to the sublingual membrane, short permanence time due to mechanical stress and swallowing and dilution of drug due to continuous secretion of saliva in the mouth. Nonetheless, the advantages and recent progress in drug delivery would outweigh the disadvantages involved (Russo et al., 2016; Salamat-Miller, Chittchang, Johnston, 2005). To overcome the limitations of buccal route of administration, mucoadhesive dosage forms have gained interest. Mucoadhesion has the capacity to improve localization of drug delivery systems by retaining the drug dosage form at the site of intended action and in contact with the absorption site like the buccal cavity (Semalty, Semalty, Kumar, 2008). Mucoadhesive formulations have been investigated for drug delivery into the oral cavity mucosa such as buccal, sublingual and gingival, eyes, nose, rectum and vagina. Among these systems, the buccal mucosa offers advantages, such as large absorption, accessibility, simple delivery devices, avoiding drug degradation and potential to incorporate drug as a controlled delivery system (Padsala, Desai, Swamy, 2014). Mefenamic acid is one of the most common nonsteroidal anti-inflammatory drugs that has the disadvantage of causing GI irritation. In order to overcome the limitations of orally administered mefenamic acid such as GI irritation, ulceration and low bioavailability, formulating a mucoadhesive buccal tablet can be useful and advantageous (Cunha, 2016). The buccal route for mefenamic acid is useful especially in the treatment of a number of oral cavity pathologies, such as stomatitis, gingivitis, periodontitis, and oral ulcers, as it can reduce inflammation by drug localization in the target tissue and also minimization of side effects (Gilhotra et al., 2014). It can also improve compliance for patients who have difficulty in swallowing orally taken medications (Raghavendra Rao, Shravani, Reddy, 2013).

\section{MATERIAL AND METHODS}

The standard, pharmaceutical and analytical grade reagents, and chemicals were purchased from Belman Laboratories and Pharmatechnica Laboratories Incorporated. Mefenamic acid pharmaceutical grade was purchased from Sigma-Aldrich.

\section{Differential scanning calorimetry}

Thermal properties of the excipients with mefenamic acid were determined with Differential Scanning
Calorimetry (DSC). Samples weighing $2 \mathrm{mg}$ were placed in a sealed aluminum pan and were heated constantly at the rate of $10 \%$ minute from $25-450{ }^{\circ} \mathrm{C}$ in air (IkeuchiTakahashi, Sasatsu, Onishi, 2013). The nitrogen purge gas flow rate was fixed to $25 \mathrm{~mL} / \mathrm{min}$ (Ito et al., 2016).

\section{Fourier transform infrared spectroscopy}

Infrared spectrum of mefenamic acid was determined using $\mathrm{KBr}$ method. The base line correction was done using dried $\mathrm{KBr}$. The spectrum of dried mixture of mefenamic acid with $\mathrm{KBr}$ was run followed by mefenamic acid with the various excipients by using FTIR spectrophotometer. The absorption maximums in spectrum obtained with the substance being studied must resemble in position and relative intensity to the reference standard spectrum (Yadav Deepak et al., 2011).

\section{Formulation}

The mucoadhesive buccal tablet was formulated using direct compression method. The excipients compatible with mefenamic acid were used. All ingredients passed through a sieve with mesh number 60 . The required quantity was taken for the formulation and it was mixed thoroughly using a blender. The blended powder was compressed using a compression machine (Cadmach Machinery Co. Pvt. Ltd., India) to produce the tablet (Yadav Deepak et al., 2011). Two batches of the most suitable formulation were prepared by direct compression.

\section{Tablet thickness and tablet diameter}

Ten tablets were randomly selected and measured using a digital vernier caliper. The tablet thickness and tablet diameter should be within $+5 \%$ variation of standard value (Fatima et al., 2015).

\section{Hardness test}

Ten tablets were randomly selected and the tablet hardness was measured using Vanguard Pharmaceutical Machinery, Inc. The in-house tablet hardness is 6.8 to $15 \mathrm{~kg}$ (Fatima et al., 2015; Velmurugan, Srinivas, 2013).

\section{Friability}

Previously weighed ten tablets were placed in an abrasion friabilator. It was rotated at $25 \mathrm{rpm}$ for 4 minutes 
for a total of 100 revolutions. After the revolutions, the tablets were placed on a \#10 sieve to remove any loose dust and were weighed again. The percent friability was calculated using the formula:

$\%$ Friability $=\frac{W \times W f}{W} \times 100$

Where Wi is the initial weight and Wf is the final weight of the tablet before and after the friability test. The percent friability must not be more than $0.8 \%$ for new formulations (Fatima et al., 2015).

\section{Disintegration test}

A $1000 \mathrm{~mL}$ beaker was filled with $900 \mathrm{~mL}$ of distilled water and was maintained at a temperature of $37+0.5^{\circ} \mathrm{C}$. Six tablets were placed in each of the cylindrical tubes of the basket. To avoid floating of the tablets, discs were used. The time taken to break the tablets into small particles was recorded. The limit for buccal tablets is 4 hours (Albreiki, Kumar, Khan, 2013).

\section{Content uniformity}

Twenty tablets were triturated using mortar and pestle and powder equivalent to one tablet was taken and dissolved in $100 \mathrm{~mL}$ phosphate buffer $(\mathrm{pH} 6.8)$ and was heated at $37{ }^{\circ} \mathrm{C}$ for 15 to 20 minutes with stirring. The solution was filtered and after suitable dilution was subjected to UV spectrophotometer at $279 \mathrm{~nm}$ for measurement of mefenamic acid content (Fatima et al., 2015).

\section{Weight variation test}

Twenty tablets were weighed together and separately using analytical balance. The average weight and percent variation of the tablet were calculated. The weight uniformity was determined according to USP specification (Fatima et al., 2015; Remington, Beringer, 2006).

\section{Moisture absorpt ion studies}

Agar at 5\% w/v was dissolved in hot water and then transferred to a petri dish and was allowed to be solidified. Prior to the study, six tablets were placed in a vacuum overnight to remove moisture. They were weighed initially and then positioned on the top of the agar and incubated at $37{ }^{\circ} \mathrm{C}$ for one hour. At the end of the test, the tablets were reweighed and the percent moisture absorption was calculated using the formula:

$\%$ Moisture Absorption $=\frac{W \times W f}{W} \times 100$

Where Wf is the final weight and Wi is the initial weight of the tablets (Velmurugan, Srinivas, 2013).

\section{Surface pH study}

The surface $\mathrm{pH}$ must be closed to the salivary $\mathrm{pH}$, so that it would not irritate the buccal mucosa. The salivary $\mathrm{pH}$ has the range of 6.5 to 7.5 . The tablets were allowed to swell for 2 hours in $1 \mathrm{~mL}$ of distilled water. The surface $\mathrm{pH}$ of the tablet was then measured using a digital $\mathrm{pH}$ meter. The $\mathrm{pH}$ electrode was placed near the surface of the tablet and was allowed to equilibrate for 1 minute before reading the measurement (Padsala, Desai, Swamy, 2014; Yadav Deepak et al., 2011).

\section{Swelling index studies}

The swelling study was performed on petri dishes containing 1\% agar gel. Four tablets were weighed and placed in a petri dish. The petri dishes contained 4 tablets, and each was placed in an incubator at $37{ }^{\circ} \mathrm{C}+$ $1{ }^{\circ} \mathrm{C}$. After $0.5,1,1.5,2,2.5,3$ hours, excess water on the surface was carefully removed using the filter paper without pressing. The tablets were reweighed and the swelling index was calculated using the formula:

Swelling Index $=\frac{W \times W f}{W} \times 100$

Where Wi is the initial weight and Wf is the final weight of the tablet (Chaudhari, Harsulkar, 2012; Hassam et al., 2009; Padsala, Desai, Swamy, 2014). Appropriate swelling property of buccal formulations is needed for proper adhesion (Sunitha et al., 2014).

\section{Mucoadhesive/bioadhesive strength}

A modified physical balance was used to measure the strength of mucoadhesiveness. The apparatus 
consisted of a double beam physical balance in which the right side has a pan, and the left side of the balance has a string that was hanged and at the bottom of the string was a suctioned glass slide. This was the place where the tablets were placed using an adhesive. The porcine buccal mucosa was placed on top of an inverted $50 \mathrm{~mL}$ beaker which was placed inside a $500 \mathrm{~mL}$ beaker that was filled with phosphate buffer with pH $6.8 \mathrm{kept}$ at $37^{\circ} \mathrm{C}$. The buffer amount was just enough so that it reaches the buccal mucosa surface. Exactly five gram of weight was placed on the right pan before putting the porcine buccal tablet in place. The weight was then removed to lower the glass slide with the attached buccal tablet. The tablet was to be in contact with the porcine buccal mucosa membrane and this was not disturbed for 5 minutes. After 5 minutes, weights were added on the right side of the pan to separate the tablet from the membrane. The accumulated weight on the right side was then noted and subtracted with $5 \mathrm{~g}$. The value was taken as the measure for the bioadhesive strength of the tablet. The bioadhesive force was calculated using the formula:

$N=\frac{W \times g}{1000}$

Where $\mathrm{N}$ is bioadhesive force, $\mathrm{W}$ is the weight required for detachment of the tablet from the porcine buccal mucosa in grams, and $\mathrm{g}$ is the acceleration due to gravity at $9.81 \mathrm{~m} / \mathrm{sec} 2$ (Fatima et al., 2015; Lodhi et al., 2013; Prasad et al., 2010). Figure 1 shows the modified physical balance.

\section{Residence time}

The residence time was tested using a modified USP dissolution apparatus. The dissolution medium was 500 mL of phosphate buffer with pH of 6.8 maintained at $37^{\circ} \mathrm{C}$. The porcine buccal mucosa was attached to a glass slide using an adhesive and was tied to the paddle of the dissolution apparatus. The tablet was hydrated using $15 \mathrm{mcL}$ of phosphate buffer and was placed in intimate contact with the porcine buccal mucosa for 30 seconds. It was then immersed in the dissolution medium and was rotated at $25 \mathrm{rpm}$. The time of displacement of the tablet from the mucosal surface was noted (Velmurugan, Srinivas, 2013). Figure 2 shows the modified dissolution apparatus.

\section{Stability in human saliva}

The stability of the buccal tablet was performed using human saliva. The study protocol and written consent form were approved by the Ethics Review Committee of the University of Santo Tomas with a protocol number GS2016-322-R1. For each test, human saliva was collected from 3 healthy human volunteers, both male and female, and with no known illnesses ages 18 years and above. The volunteers were informed about the nature of the research which does not involve any health risks. The saliva collected was only used for stability testing of the buccal tablet and was filtered using filter paper. Approximately 5 $\mathrm{mL}$ of human saliva were collected and placed in a petri dish. The buccal tablet was placed in the petri dish and was put in an oven for 3 hours at $37^{\circ} \mathrm{C}+0.2{ }^{\circ} \mathrm{C}$ at regular intervals with $0,1,2$ and 3 hours. The buccal tablet was observed for changes in appearance such as shape, color, collapse of the tablet, and change in $\mathrm{pH}$ (Choi, Kim, 2000; Fatima et al., 2015; Velmurugan, Srinivas, 2013).

\section{Drug release}

In-vitro drug release studies were tested using USP dissolution test apparatus II, the paddle type with dissolution medium of phosphate buffer with a $\mathrm{pH}$ of 6.8. It was performed at $37{ }^{\circ} \mathrm{C}+0.5^{\circ} \mathrm{C}$ with a speed of $50 \mathrm{rpm}$. The sample at $5 \mathrm{~mL}$ was withdrawn at time interval of $15,30,45,60,90,120,150,180$ minutes and was replaced with $5 \mathrm{~mL}$ of fresh phosphate buffer. The amount of mefenamic acid was determined at 279 nm using UV spectrophotometer (Vikram et al., 2012; Yadav Deepak et al., 2011).

\section{Stability study}

The tablets were stored for 3 months and the samples were tested after a period of 30,60, and 90 days (Yadav Deepak et al., 2011). The samples were analyzed using the quality control tests such as hardness, friability, thickness, content uniformity, weight variation, and moisture absorption studies and in-vitro tests such as swelling studies, mucoadhesive strength, stability in human saliva, and drug release.

\section{Statistical analysis}

Means and its standard errors were used to summarize the data gathered in the research. Two- 
factor analysis of variance (ANOVA) was used to compare the residence time, moisture absorption and mucoadhesive strength of the tablets across the different batches and month. In repeated measures,
ANOVA was used in the comparison of the percent release and percent swelling. All the statistical tests were performed in SPSS version 20.0 at 5\% level of significance.

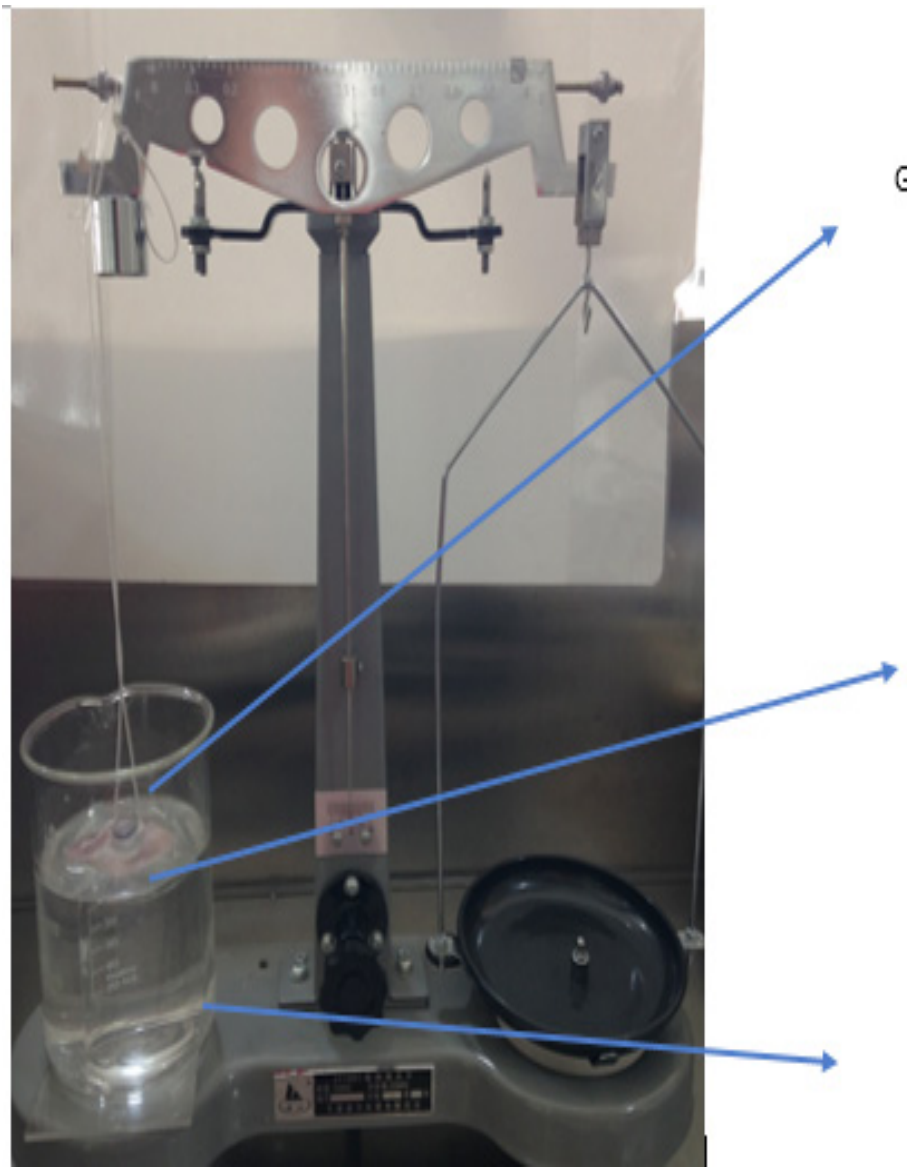

Glass slide with buccal tablet

\author{
Inverted small vessel \\ ( $50 \mathrm{~mL}$ glass beaker) \\ containing the buccal \\ mucosa
}

Outer large vessel ( $500 \mathrm{~mL}$ beaker) filled with $\mathrm{pH} 6.8$ phosphate buffer

FIGURE 1 - Modified physical balance for mucoadhesive studies.

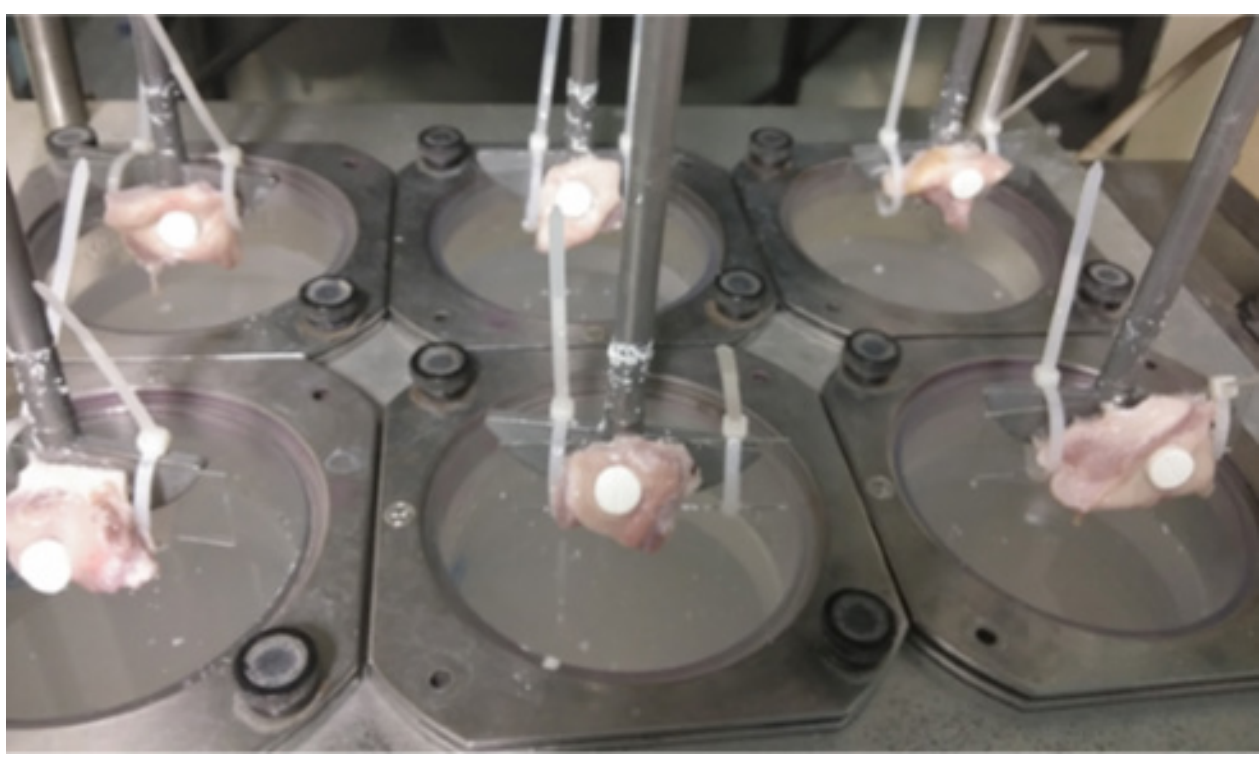

FIGURE 2 - Residence time using modified dissolution apparatus. 


\section{RESULTS AND DISCUSSION}

\section{Compatibility tests of mefenamic acid with excipients}

DSC studies were conducted on the pure drug (mefenamic acid) and the excipients of the formulation to check for the compatibility. Figures 3 and 4 show the DSC result of mefenamic acid and the ingredients used in the formulation.

The DSC results of all the excipients show no interaction with mefenamic acid, the active ingredient. Even after one month at $40^{\circ} \mathrm{C}$, there were no significant changes in the peaks. The DSC result of the formulation as shown in Figure 4 exhibited no interaction with the excipients, since there were no changes in the appearance of the peaks. Even after one month at $40{ }^{\circ} \mathrm{C}$, result showed that there is no thermal incompatibility between the ingredients.

The physicochemical compatibility of the pure drug (mefenamic acid) and the excipients in the formulation were verified and established through FTIR.

The spectra of mefenamic acid (pure drug) showed peaks at $3315.92 \mathrm{~cm}^{-1}$ (N-H stretch), $1654.1 \mathrm{~cm}^{-1}(\mathrm{C}=\mathrm{O}$ stretch), $1579.6 \mathrm{~cm}^{-1}$ (N-H bending), $1505 \mathrm{~cm}^{-1}(\mathrm{C}=\mathrm{C}$ stretch) and $759.47 \mathrm{~cm}^{-1}$ (aromatic stretch).

All the characteristic peaks that were seen in the active ingredient were also found in the spectra of mefenamic acid with the excipients. This shows that there is no incompatibility between mefenamic acid and the excipients. Likewise, the spectra of the formulation showed the peaks found in the pure drug. The spectra of the formulation showed peaks at $3307.5 \mathrm{~cm}^{-1}(\mathrm{~N}-\mathrm{H}$ stretch), $1658.4 \mathrm{~cm}^{-1}$ (C=O stretch), $1577.5 \mathrm{~cm}^{-1}(\mathrm{~N}-\mathrm{H}$ bending), $1507.5 \mathrm{~cm}^{-1}(\mathrm{C}=\mathrm{C}$ stretch $)$ and $755.6 \mathrm{~cm}^{-1}$ (aromatic stretch). All the characteristic peaks in the mefenamic acid spectra were also found in the spectra of the formulation and even after one month at $40{ }^{\circ} \mathrm{C}$, same peaks were seen in the spectra. This indicates that there is no significant interaction between the drugs and the excipients.

Based on DSC and FTIR results, the excipients compatible with mefenamic acid are the following: sodium alginate, Hydroxypropylmethylcellulose K4M (HPMC K4M), Sodium Carboxymethylcellulose (SCMC), and magnesium stearate. These excipients were used in the trial formulation of a mucoadhesive buccal tablet.

\section{Formulation of mucoadhesive buccal tablet for mefenamic acid}

Four formulations of a mucoadhesive buccal tablet were prepared as shown in Table I. Among the formulations, formula 4 was chosen since it did not exhibit any problems such as capping, lamination, and with drug release which were encountered in other formulations.

Formula 1, 2 and 3 exhibited capping and lamination where the tablets are separated into layers. This may be due to air entrapped inside the tablet or may be due to the formulation of the tablet (Kasture et al., 2008). Formula 1 and 2 exhibited different drug release over time, which can mean that the formulations are not stable. Only Formulation 4 exhibited a drug release of at least $80 \%$ and the physicochemical properties of the formulated tablet are described in Table II.

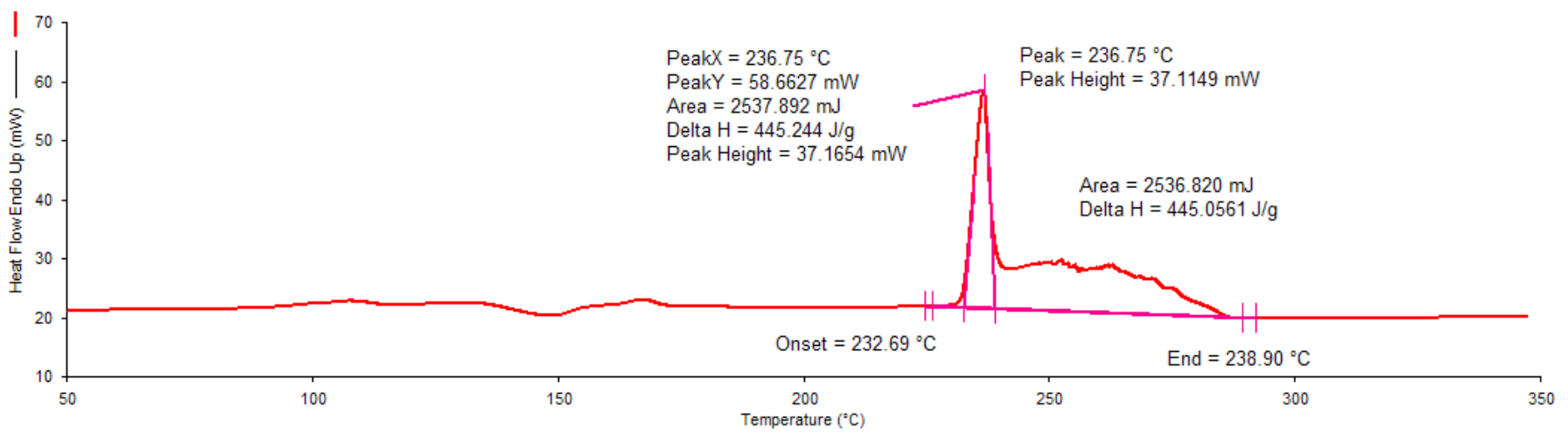

FIGURE 3 - DSC result of mefenamic acid. 


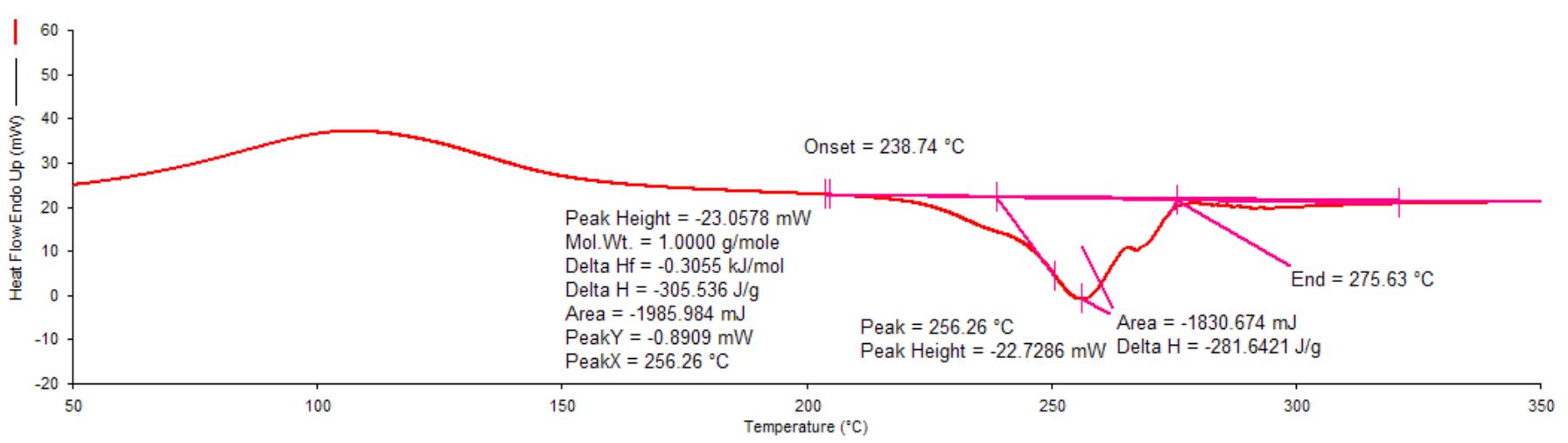

a

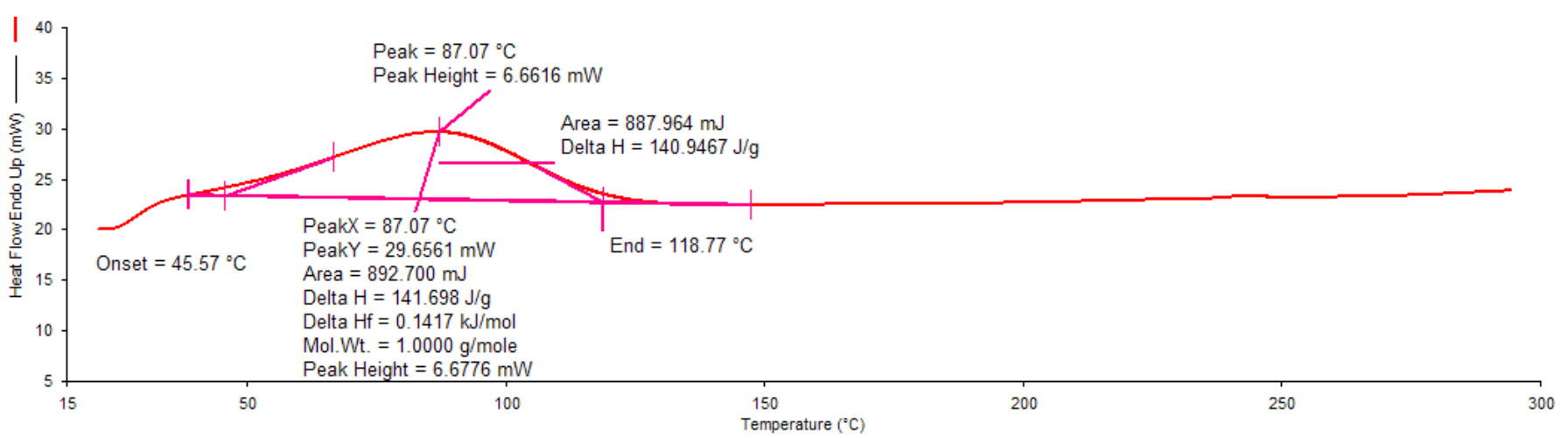

$\mathrm{b}$

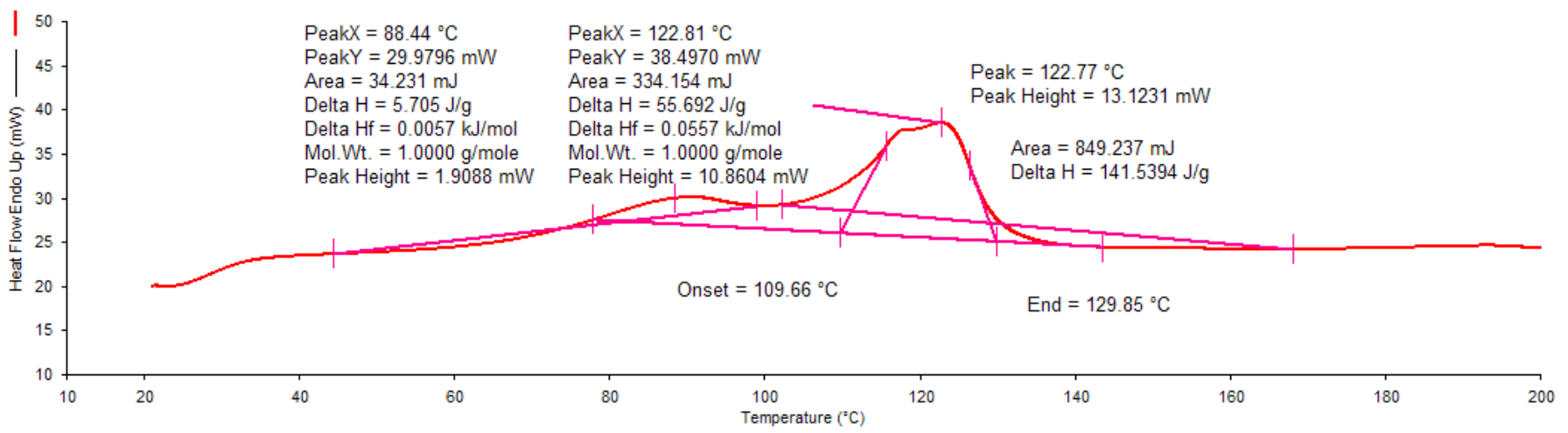

c

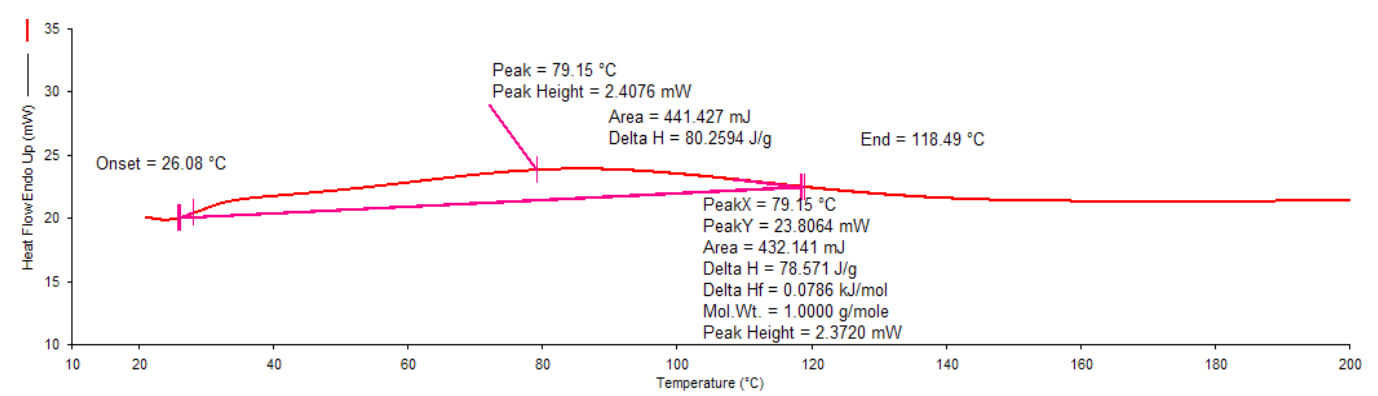

d

FIGURE 4 - a. DSC Result of a. Sodium Alginate; b. Hydroxypropylmethylcellulose K4M (HPMC K4M); c. Sodium Carboxymethylcellulose (SCMC); and d. Magnesium Stearate. 


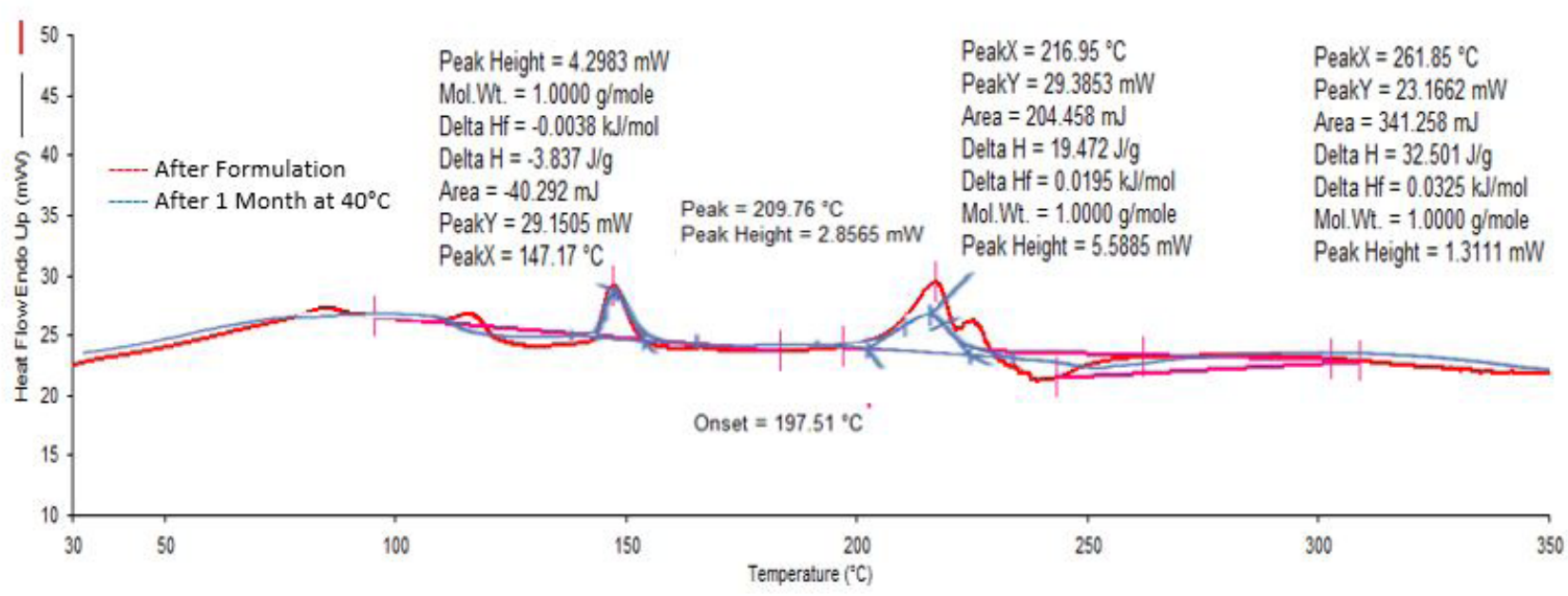

FIGURE 5 - DSC result of the excipients with mefenamic acid.

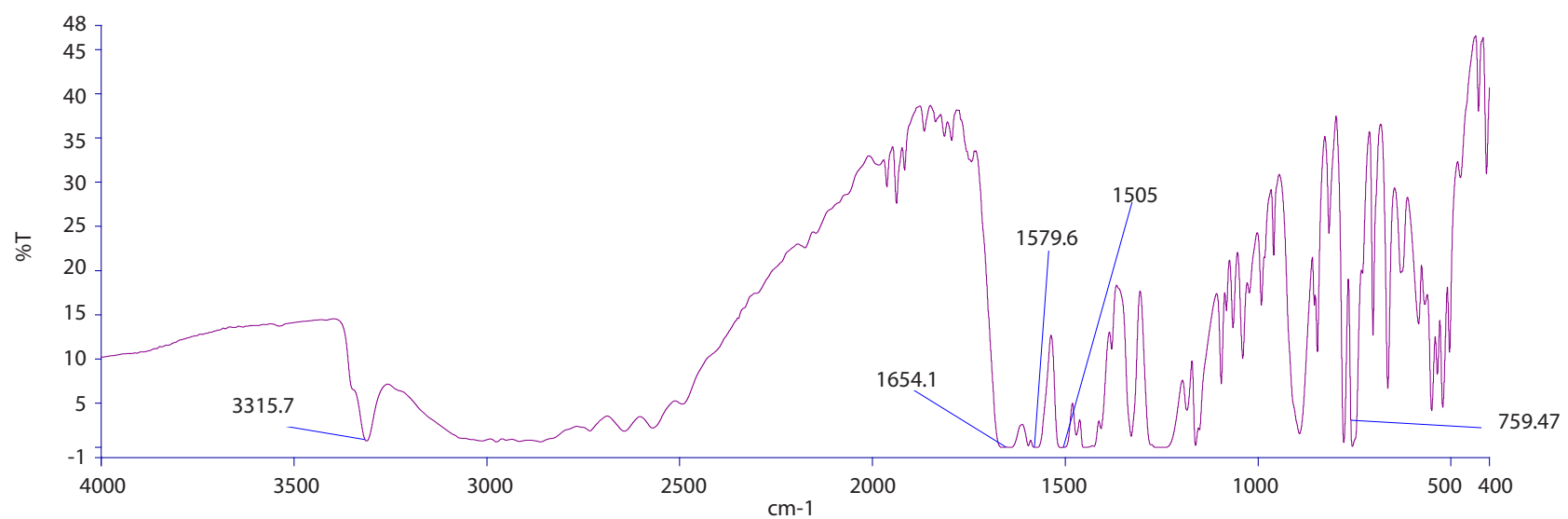

FIGURE 6 - FTIR spectra of mefenamic acid. 


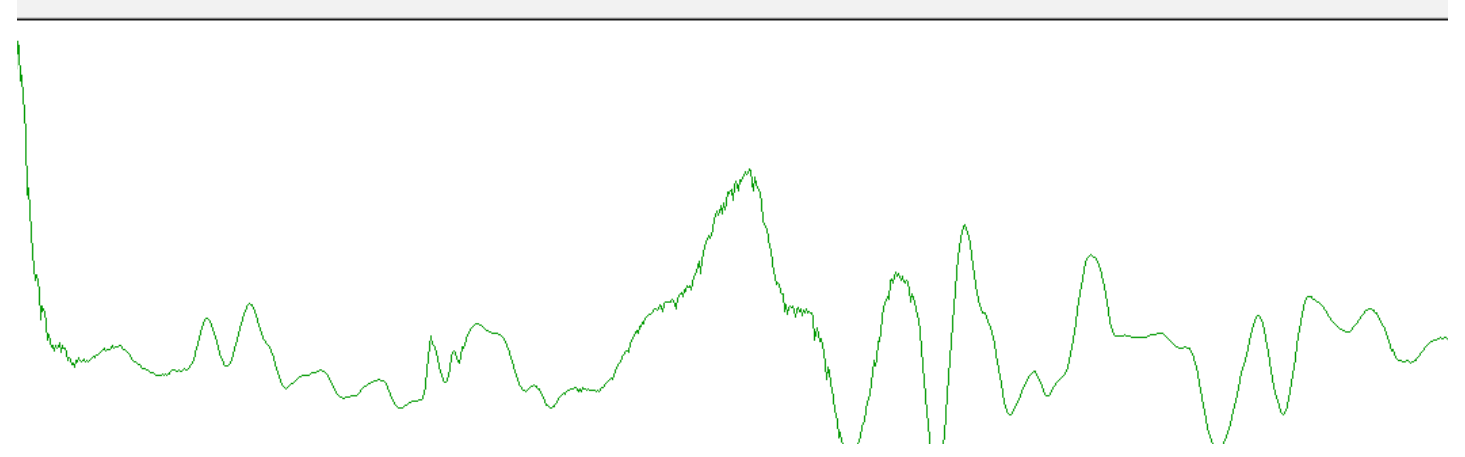

\section{a. Sodium Alginate}

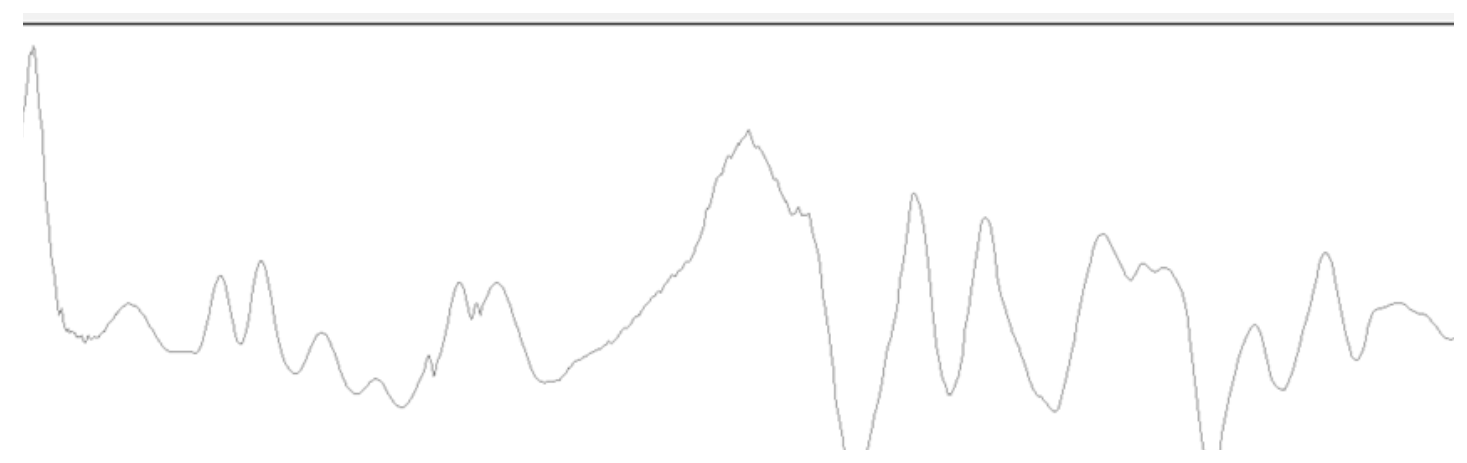

b. HPMC K4M

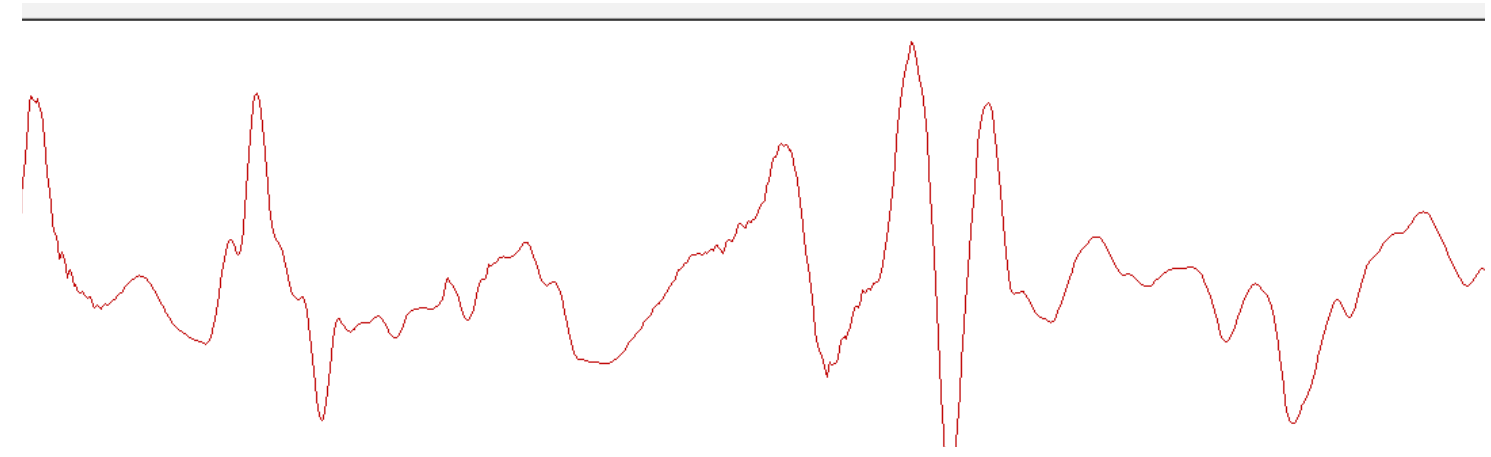

c. SCMC

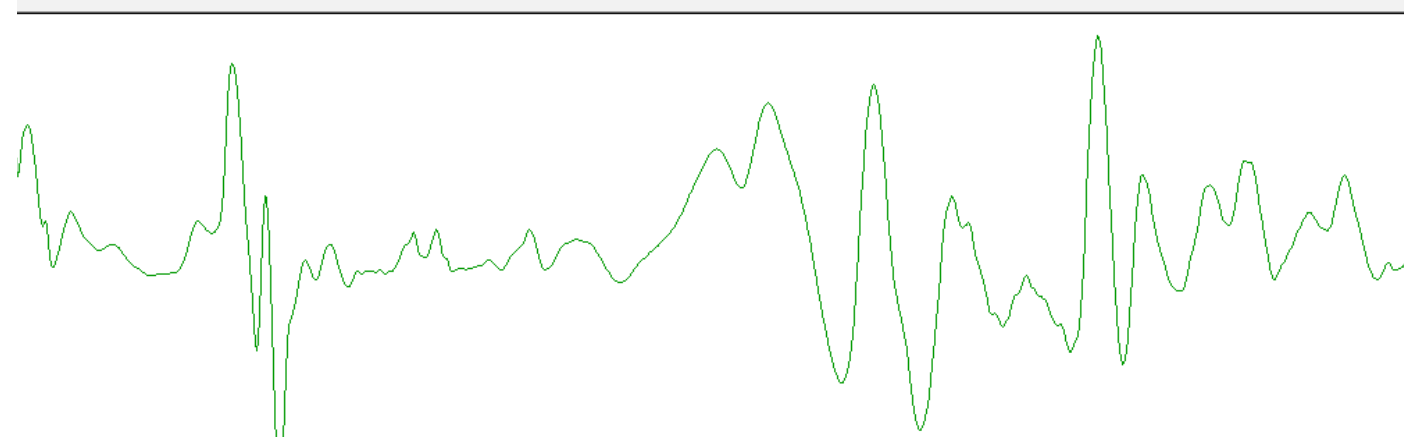

d. Magnesium Stearate

FIGURE 7 - FTIR result of a. Sodium Alginate; b. Hydroxypropylmethylcellulose K4M (HPM K4M); c. Sodium Carboxymethylcellulose (SCMC); and d. Magnesium Stearate. 


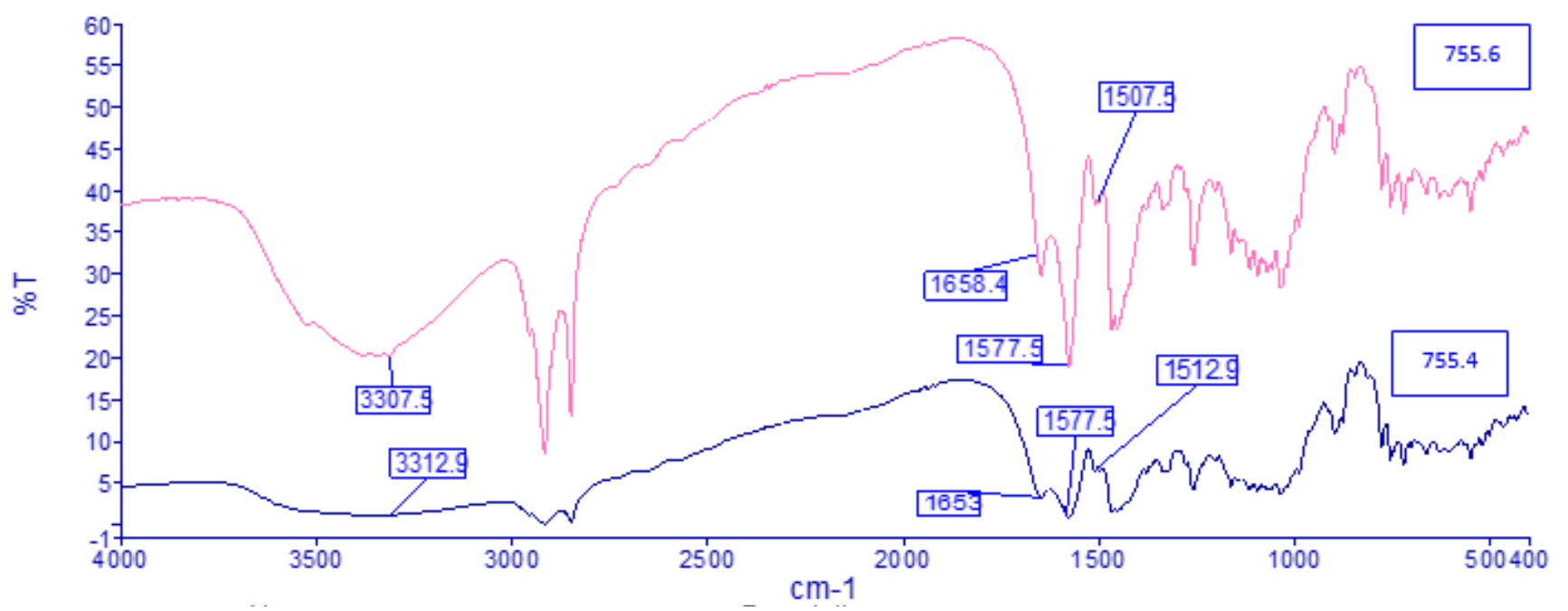

FIGURE 8 - FTIR spectra of all the ingredients initially and after one month at $40{ }^{\circ} \mathrm{C}$.

TABLE I - Problems encountered in the formulated mucoadhesive buccal tablet for mefenamic acid

\begin{tabular}{|c|c|c|c|c|}
\hline \multirow{2}{*}{ Ingredients } & \multicolumn{4}{|c|}{ Formula } \\
\hline & 1 & 2 & 3 & 4 \\
\hline Mefenamic Acid & $500 \mathrm{mg}$ & $500 \mathrm{mg}$ & $250 \mathrm{mg}$ & $250 \mathrm{mg}$ \\
\hline Sodium Alginate & $36 \mathrm{mg}$ & $36 \mathrm{mg}$ & $30 \mathrm{mg}$ & $30 \mathrm{mg}$ \\
\hline HPMC K4M & $36 \mathrm{mg}$ & $57 \mathrm{mg}$ & $189 \mathrm{mg}$ & $30 \mathrm{mg}$ \\
\hline SCMC & $57 \mathrm{mg}$ & $36 \mathrm{mg}$ & $30 \mathrm{mg}$ & $189 \mathrm{mg}$ \\
\hline Magnesium Stearate & $1 \mathrm{mg}$ & $1 \mathrm{mg}$ & $1 \mathrm{mg}$ & $1 \mathrm{mg}$ \\
\hline Total weight & $630 \mathrm{mg}$ & $630 \mathrm{mg}$ & $500 \mathrm{mg}$ & $500 \mathrm{mg}$ \\
\hline Problems Encountered & $\begin{array}{c}\text { Capping, Lamination, } \\
\text { Drug Release }\end{array}$ & $\begin{array}{c}\text { Capping, Lamination, } \\
\text { Drug Release }\end{array}$ & Capping, Lamination & $\begin{array}{l}\text { No Problems } \\
\text { Encountered }\end{array}$ \\
\hline
\end{tabular}




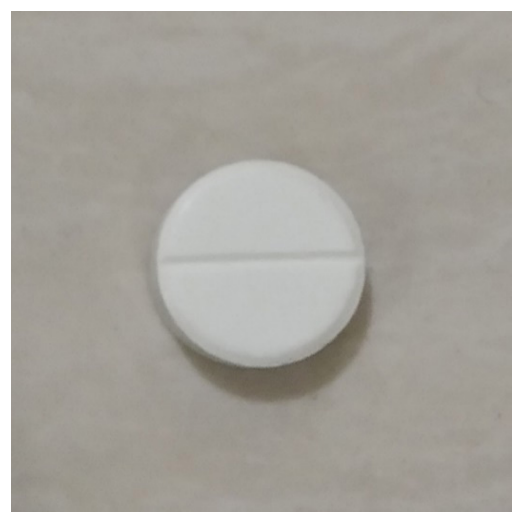

FIGURE 9 - Mucoadhesive buccal tablet of mefenamic acid.

TABLE II - Physicochemical properties of the formulated mucoadhesive buccal tablet of mefenamic acid

Tests

Color

Shape

Tablet Weight (mg)

Hardness (kg)

Thickness (mm)

Diameter (mm)

Friability (\%)

Disintegration (min.)

Content Uniformity (\%)

Moisture absorption (\%)

Surface $\mathrm{pH}$

Swelling (\%) after 3 hours

Mucoadhesive Strength

Residence Time (min.)

Drug Release After 3 hours

\section{Batch 1}

White

Round

$504.13 \pm 1.08$

$10.40 \pm 0.20$

$3.74 \pm 0.01$

$12.085 \pm 0.004$

$0.277 \pm 0.052$

$147.37 \pm 3.00$

$107.83 \pm 0.68$

$15.09 \pm 0.39$

$6.99 \pm 0.08$

$55.90 \pm 1.92$

$0.197 \pm 0.003$

$14.03 \pm 0.57$

$83.4 \pm 1.8$
Batch 2

White

\section{Round}

$512.43 \pm 1.00$

$9.93 \pm 0.18$

$3.79 \pm 0.01$

$12.056 \pm 0.002$

$0.300 \pm 0.005$

$147.70 \pm 3.41$

$105.61 \pm 0.95$

$15.27 \pm 0.75$

$6.98 \pm 0.08$

$54.03 \pm 0.50$

$0.200 \pm 0.002$

$13.58 \pm 0.54$

$80.7 \pm 0.1$ 


\section{Quality control tests}

All the quality control tests were performed in triplicates using the 2 batches of Formula 4, which were prepared by the researcher.

\section{Tablet thickness and tablet diameter}

All the tablets are within the acceptable range for tablet thickness with values ranging from $3.71 \mathrm{~mm}$ to $3.80 \mathrm{~mm}$. Tablet diameter of the tablets showed values ranging from $12.01 \mathrm{~mm}$ to $12.08 \mathrm{~mm}$, which fall within the acceptable range. After 3 months of subjecting the tablets at $40{ }^{\circ} \mathrm{C} / 75 \% \mathrm{RH}$, the tablets are still within the acceptable range for tablet thickness and diameter as shown in Tables V and VI.

\section{Hardness test}

The tablet hardness shows that all tablets are within the range. The results show acceptable resistance of the tablet to shipping during storage and transport. All the tablets fall within the in-house hardness range of $6.8 \mathrm{~kg}$ to $15 \mathrm{~kg}$. Even after stability testing, all tablets fall within the acceptable range as shown in Tables V and VI.

\section{Friability test}

The percent friability should not be more than $0.8 \%$ for new formulations. All tablets are within range, therefore, the tablet is resistant to breaking due to storage and transportation as shown in Tables V and VI.

\section{Disintegration test}

All the tablets disintegrated before 240 minutes. Even after 3 months of stability test, all tablets still disintegrated within 240 minutes as shown in Tables $\mathrm{V}$ and VI.

\section{Content uniformity test}

According to USP, the tablet content should be within the range of $85 \%$ to $115 \%$ and no unit is outside the range of $75 \%$ to $125 \%$ and the relative standard deviation should be less than or equal to $6 \%$. All fall within the range of $85 \%$ to $115 \%$ with a relative standard deviation of less than or equal to $6 \%$. Even after 3 months of subjecting the tablets to $40{ }^{\circ} \mathrm{C} / 75 \%$ $\mathrm{RH}$, all tablets fall within the acceptable range as shown in Tables V and VI.

\section{Weight variation test}

The specification of tablet weight with $500 \mathrm{mg}$ is $\pm 5 \%$ difference as shown in Tables V and VI. The tablet weights should be $475 \mathrm{mg}$ to $525 \mathrm{mg}$. As shown in Tables $\mathrm{V}$ and VI, all tablets fall within the specified limits and even after 3 months of stability testing, all results fall within the range of $475 \mathrm{mg}$ to $525 \mathrm{mg}$.

\section{Moisture absorption studies}

Moisture absorption of the mucoadhesive buccal tablets is in the range of $14.07 \%$ to $16.65 \%$. There was no significant change in the percent moisture absorption even after 3 months of stability test, which shows that the tablets have suitable moisture absorption capacity.

There was no significant difference in the mean moisture absorption of the two batches $[F 1,16=0.240$, $\mathrm{p}=0.631]$. Likewise, the mean moisture absorption at baseline and after one, two and three months did not differ [F3, 16 $=0.148, p=0.939]$. Results show that even after 3 months of stability studies, the percent moisture absorption did not differ from the baseline.

\section{Surface pH study}

The surface $\mathrm{pH}$ of the tablet should be close to the salivary $\mathrm{pH}$ so that the tablet will not irritate the buccal mucosa. The salivary $\mathrm{pH}$ is 6.50 to 7.50 . Since the surface $\mathrm{pH}$ of the buccal tablet is within the limits of salivary $\mathrm{pH}$, it shows that the tablet will not irritate the buccal mucosa.

\section{In-vitro tests for mucoadhesive buccal tablet}

\section{Swelling index study}

The percent swelling of batch 1 and batch 2 baselines after 3 hours were $55.90 \%$ and $54.03 \%$, respectively. After one to three months of subjecting the tablets to $40{ }^{\circ} \mathrm{C}$ and $75 \% \mathrm{RH}$, the percent swelling of batch 1 was $58.86 \%, 53.83 \%$ and $54.89 \%$, respectively, while for batch 2 , the percent swelling was $58.14 \%, 55.05 \%$ and $54.94 \%$, respectively. 


\section{Graph of Percent Swelling vs Time (hours)}

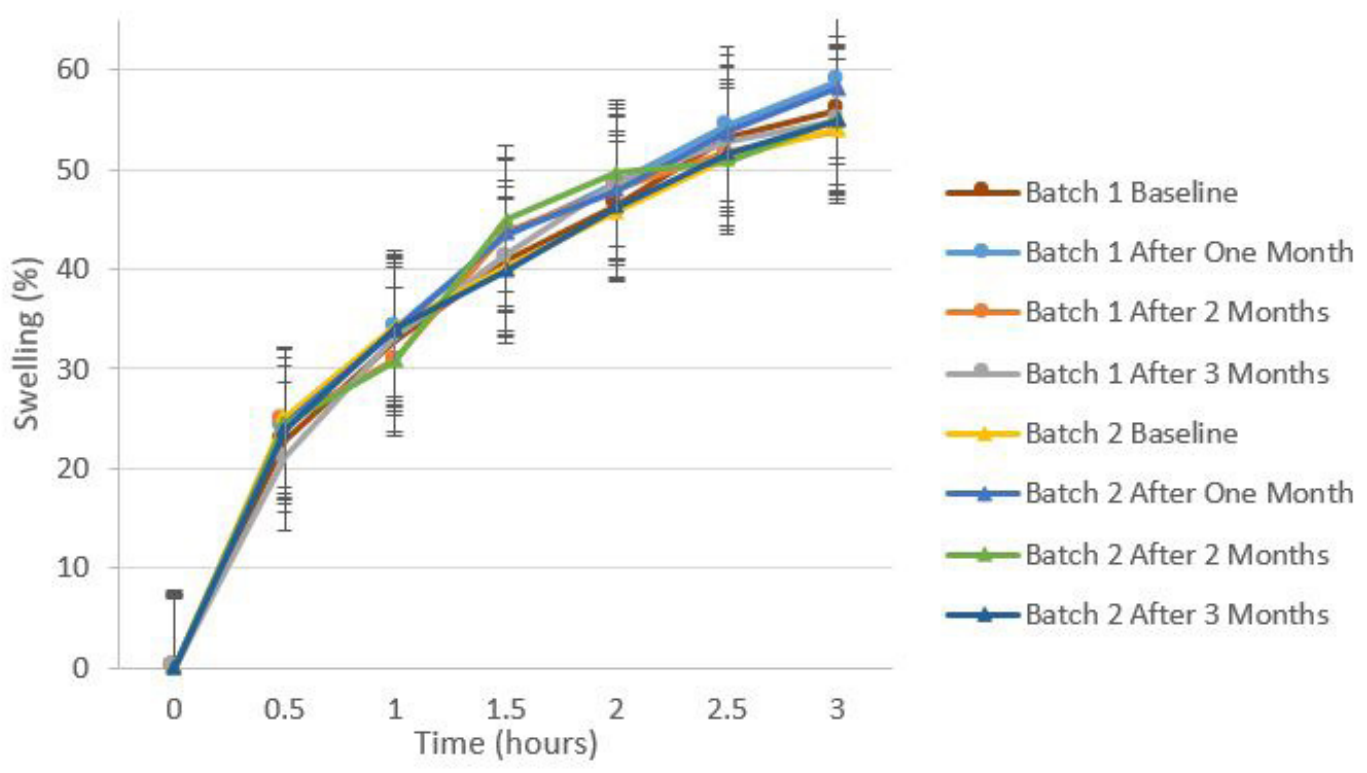

FIGURE 10 - Graph of percent swelling vs. Time in hours.

Results of the analysis of variance for repeated measures showed that the interaction effect of Time, Month, and Batch is not significant $[\mathrm{F} 18,96=0.580$, $\mathrm{p}=0.906]$ and even after 3 months of stability test $[F 3,16=0.082, p=0.969]$, where the results show that there was no significant difference from the results acquired after formulation at baseline.

\section{Mucoadhesive/bioadhesive strength}

The mucoadhesive strength of batch 1 was 0.197 , $0.196,0.197$, and 0.198 , respectively from 0 to 3 months of stability testing, while that of batch 2 was 0.200 , $0.199,0.198$, and 0.198 . There was no significant change in the mucoadhesive strength even after 3 months of stability test, which show that the buccal tablets have maintained their bioadhesive strength. There was no significant difference in the mean mucoadhesive strength of the two batches [F1, 64 $=0.993, p=0.323$ ]. Likewise, the mean mucoadhesive strength at baseline and after one, two and three months did not differ [F3, 64 $=0.102, p=0.958]$. There was a sufficient mucoadhesive strength of the tablets and it did not significantly change even after stability studies for 3 months at $40{ }^{\circ} \mathrm{C}$ and $75 \% \mathrm{RH}$ as shown in Tables $\mathrm{V}$ and VI.

\section{Residence time}

Residence time is the time of displacement of the tablet from the porcine buccal membrane. The average residence time of batch 1 and batch 2 were 14.03 minutes and 13.58 minutes, respectively. After one month of stability study, the residence time of batch 1 and batch 2 are shown in Tables IV and V.

There was no significant interaction effect in the batch and time $[\mathrm{F} 3,136=0.421, \mathrm{p}=0.738]$. There was also no significant difference in the mean residence time of the two batches [F1, 136 $=0.213, \mathrm{p}=0.645]$. However, the mean residence time at baseline is significantly higher than after one month $(p=0.016)$, but did not differ after two $(p=0.347)$ and three months $(p=0.946)$. Results show suitable residence time of the tablets. There was no significant difference in the residence time of the baseline and after 3 months of stability studies.

\section{Stability in human saliva}

Changes in the buccal tablet would indicate that the drug is unstable in human saliva. The results show that there were no changes in terms of color, shape, collapse of tablet and $\mathrm{pH}$. Same results were seen even at 1, 2, and 3 months of stability studies. Since there were no changes, the buccal tablets have sufficient stability in human saliva. 


\section{Drug release}

The average drug release of the mucoadhesive mefenamic acid buccal tablet is shown in Table III.

The interaction effect of Time, Month, and Batch is significant $[\mathrm{F} 8,128=1.813, \mathrm{p}<0.001]$. The mean percent release of the two batches [F1, 16 $=6.305, \mathrm{p}=0.023$ ] significantly differ, indicating that batch 1 is significantly higher than batch 2 . However, there is also no significant difference in the mean percent release at baseline, after one, two and three months [F3, $16=0.0829, \mathrm{p}=0.497]$. The main effect of Time [F8, 128 $=1434.733, \mathrm{p}<0.001]$ was significant, which shows that regardless of the batch and time, the mean percent release continuously increases over time in minutes. Results show the potential of the formulation as a mucoadhesive buccal tablet of mefenamic acid.

Table IV shows the drug release of the formulated mucoadhesive buccal tablet compared to mefenamic acid products available in the market.

TABLE III - Average drug release of the mucoadhesive mefenamic acid buccal tablet during stability test

\begin{tabular}{|c|c|c|c|c|c|c|c|c|}
\hline \multirow{2}{*}{$\begin{array}{l}\text { Time } \\
(\min )\end{array}$} & \multicolumn{2}{|c|}{ Month 0} & \multicolumn{2}{|c|}{ Month 1} & \multicolumn{2}{|c|}{ Month 2} & \multicolumn{2}{|c|}{ Month 3} \\
\hline & Batch 1 & Batch 2 & Batch 1 & Batch 2 & Batch 1 & Batch 2 & Batch 1 & Batch 2 \\
\hline 0 & $0 \%$ & $0 \%$ & $0 \%$ & $0 \%$ & $0 \%$ & $0 \%$ & $0 \%$ & $0 \%$ \\
\hline 15 & $23.37 \%$ & $15.85 \%$ & $23.01 \%$ & $16.98 \%$ & $24.12 \%$ & $20.62 \%$ & $27.50 \%$ & $19.14 \%$ \\
\hline 30 & $39.65 \%$ & $29.20 \%$ & $43.20 \%$ & $33.81 \%$ & $38.10 \%$ & $44.76 \%$ & $41.61 \%$ & $34.93 \%$ \\
\hline 45 & $48.43 \%$ & $42.06 \%$ & $48.24 \%$ & $47.19 \%$ & $41.88 \%$ & $56.67 \%$ & $49.91 \%$ & $44.93 \%$ \\
\hline 60 & $54.28 \%$ & $47.43 \%$ & $59.35 \%$ & $49.54 \%$ & $44.87 \%$ & $61.90 \%$ & $50.15 \%$ & $49.77 \%$ \\
\hline 90 & $63.37 \%$ & $49.19 \%$ & $71.59 \%$ & $53.72 \%$ & $54.31 \%$ & $64.89 \%$ & $57.40 \%$ & $56.51 \%$ \\
\hline 120 & $68.83 \%$ & $56.45 \%$ & $72.48 \%$ & $57.18 \%$ & $65.09 \%$ & $69.12 \%$ & $70.64 \%$ & $69.55 \%$ \\
\hline 150 & $73.72 \%$ & $68.31 \%$ & $80.41 \%$ & $66.62 \%$ & $67.87 \%$ & $70.94 \%$ & $75.09 \%$ & $72.93 \%$ \\
\hline 180 & $83.45 \%$ & $80.68 \%$ & $82.70 \%$ & $80.76 \%$ & $82.55 \%$ & $80.96 \%$ & $83.15 \%$ & $80.78 \%$ \\
\hline
\end{tabular}




\section{Graph of Percent Drug Release vs Time (minutes)}

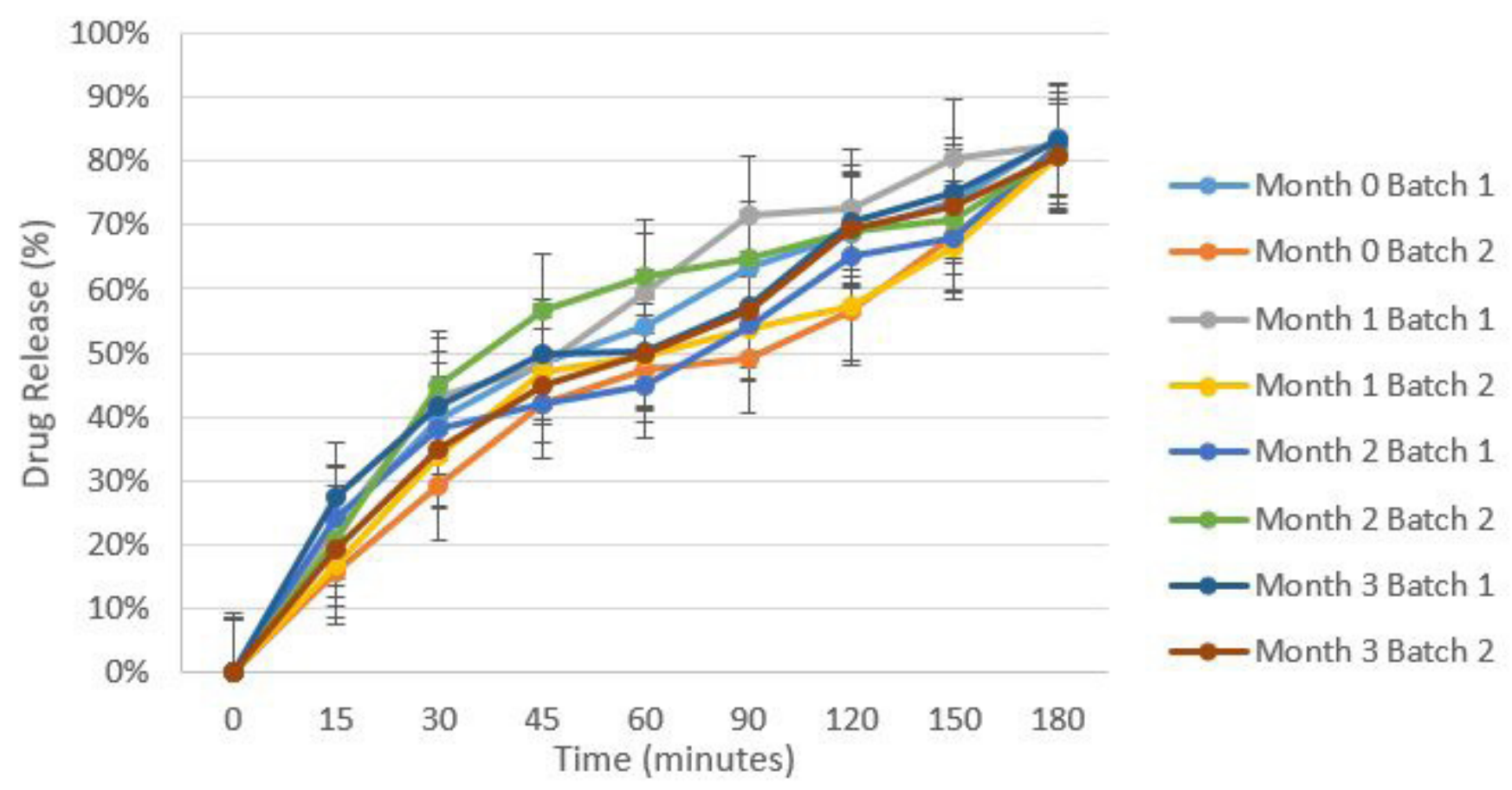

FIGURE 11 - Graph of percent release vs. time in minutes.

TABLE IV - Summary drug release of $250 \mathrm{mg}$ mefenamic acid products available in market and $250 \mathrm{mg}$ of the formulated mucoadhesive buccal tablet

\begin{tabular}{lccccccccc}
\hline & \multicolumn{7}{c}{ Time (mins.) } \\
\cline { 2 - 9 } Drug Release (\%) & $\mathbf{0}$ & $\mathbf{1 5}$ & $\mathbf{3 0}$ & $\mathbf{4 5}$ & $\mathbf{6 0}$ & $\mathbf{9 0}$ & $\mathbf{1 2 0}$ & $\mathbf{1 5 0}$ & $\mathbf{1 8 0}$ \\
\hline $\begin{array}{l}\text { Formulated } \\
\text { Buccal Tablet }\end{array}$ & 0 & 23.3 & 38.3 & 47.4 & 50.0 & 57.0 & 70.1 & 74.0 & 82.0 \\
Brand A capsule & 0 & 17.2 & 36.1 & 44.4 & 35.4 & 54.3 & 58.9 & 62.5 & 69.5 \\
Brand B tablet & 0 & 29.4 & 42.6 & 64.5 & 65.1 & 70.6 & 72.2 & 74 & 77.9 \\
\hline
\end{tabular}

Results showed that after 3 hours, the percent drug release of the formulated mucoadhesive buccal tablet, Brand A $250 \mathrm{mg}$ capsule, and Brand B $250 \mathrm{mg}$ tablet is at $82 \%, 69.5 \%$, and $77.9 \%$, respectively.

The mean percentage release of the formulation is significantly higher than Brand A capsule $(\mathrm{p}<0.001)$ and Brand B tablet $(\mathrm{p}=0.023)$ after 180 minutes. But in general, compared with the commercially available product, the mean percentage release of the formulation did not differ with Brand A capsule $(\mathrm{p}=0.122)$ and Brand B tablet $(p=0.060)$. 
Results show the potential of the formulation as a mucoadhesive buccal tablet of mefenamic acid.

\section{Graph of Percent Drug Release vs Time (minutes)}

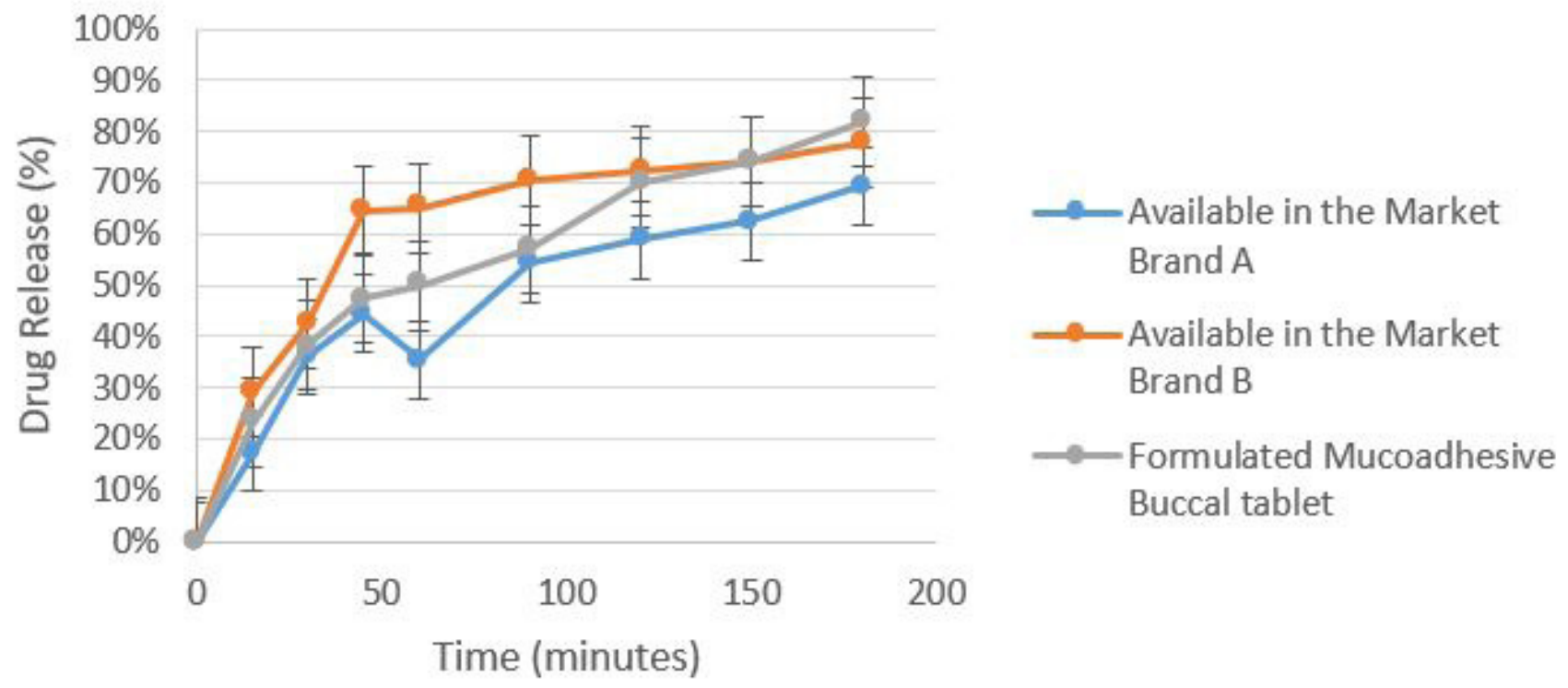

FIGURE 12 - Drug release graph of mefenamic acid $(250 \mathrm{mg})$ products available in market and the formulated mefenamic acid (250 mg) mucoadhesive buccal tablet.

\section{Stability study}

All tests conform within the specifications even after three months of subjecting the tablets to $40{ }^{\circ} \mathrm{C} / 75 \%$
RH. Summary of the results of batch 1 and batch 2 are shown in Table V and Table VI respectively.

TABLE V - Summary of the results for batch 1: formulated mucoadhesive mefenamic acid buccal tablet

\section{Batch 1}

\begin{tabular}{|c|c|c|c|c|c|c|c|}
\hline \multirow[b]{2}{*}{ Tests } & & \multirow{2}{*}{$\begin{array}{c}\text { Percent } \\
\text { Change } \\
(\%)\end{array}$} \\
\hline & Month 0 & Month 1 & $\begin{array}{c}\text { Percent } \\
\text { Change }(\%)\end{array}$ & Month 2 & $\begin{array}{c}\text { Percent } \\
\text { Change }(\%)\end{array}$ & Month 3 & \\
\hline $\begin{array}{l}\text { Weight } \\
\text { Variation (mg) }\end{array}$ & $504.13 \pm 1.08$ & $503.53 \pm 1.13$ & 0.12 & $504.51 \pm 1.31$ & 0 & $505.19 \pm 1.13$ & 0.21 \\
\hline Thickness (mm) & $3.74 \pm 0.01$ & $3.74 \pm 0.02$ & 0 & $3.72 \pm 0.01$ & 0.53 & $3.71 \pm 0.01$ & 0.80 \\
\hline
\end{tabular}


TABLE V - Summary of the results for batch 1: formulated mucoadhesive mefenamic acid buccal tablet

\begin{tabular}{|c|c|c|c|c|c|c|c|}
\hline \multirow[b]{2}{*}{ Tests } & \multicolumn{6}{|c|}{ Batch 1} & \multirow{2}{*}{$\begin{array}{c}\text { Percent } \\
\text { Change } \\
(\%)\end{array}$} \\
\hline & Month 0 & Month 1 & $\begin{array}{c}\text { Percent } \\
\text { Change (\%) }\end{array}$ & Month 2 & $\begin{array}{c}\text { Percent } \\
\text { Change (\%) }\end{array}$ & Month 3 & \\
\hline Diameter (mm) & $12.085 \pm 0.004$ & $12.090 \pm 0.005$ & 0.04 & $\begin{array}{c}12.042 \pm \\
0.005\end{array}$ & 0.36 & $12.013 \pm 0.005$ & 0.60 \\
\hline Friability (\%) & $0.277 \pm 0.052$ & $0.313 \pm 0.058$ & 13.00 & $0.280 \pm 0.006$ & 1.08 & $0.277 \pm 0.052$ & 0 \\
\hline $\begin{array}{l}\text { Disintegration } \\
\text { (min.) }\end{array}$ & $147.37 \pm 3.00$ & $155.25 \pm 3.38$ & 5.60 & $154.12 \pm 1.77$ & 4.58 & $154.99 \pm 2.09$ & 5.17 \\
\hline $\begin{array}{l}\text { Content } \\
\text { Uniformity (\%) }\end{array}$ & $107.83 \pm 0.68$ & $106.58 \pm 0.81$ & 1.16 & $101.03 \pm 0.58$ & 6.31 & $102.97 \pm 0.81$ & 4.51 \\
\hline $\begin{array}{l}\text { Moisture } \\
\text { absorption (\%) }\end{array}$ & $15.09 \pm 0.39$ & $15.68 \pm 0.38$ & 3.91 & $15.56 \pm 0.54$ & 3.11 & $15.09 \pm 0.2$ & 0 \\
\hline Surface $\mathrm{pH}$ & $6.99 \pm 0.08$ & $6.83 \pm 0.07$ & 2.29 & $6.79 \pm 0.04$ & 2.86 & $6.72 \pm 0.04$ & 3.86 \\
\hline $\begin{array}{l}\text { Swelling (\%) } \\
\text { after } 3 \text { hours }\end{array}$ & $55.90 \pm 1.92$ & $58.86 \pm 1.55$ & 5.30 & $53.83 \pm 0.84$ & 3.70 & $54.89 \pm 1.00$ & 1.81 \\
\hline $\begin{array}{l}\text { Mucoadhesive } \\
\text { Strength }\end{array}$ & $0.197 \pm 0.003$ & $0.196 \pm 0.002$ & 0.51 & $0.197 \pm 0.003$ & 0 & $0.198 \pm 0.003$ & 0.51 \\
\hline $\begin{array}{l}\text { Residence } \\
\text { Time (min.) }\end{array}$ & $14.03 \pm 0.57$ & $12.65 \pm 0.35$ & 9.84 & $13.13 \pm 0.36$ & 6.41 & $13.84 \pm 0.26$ & 1.35 \\
\hline $\begin{array}{l}\text { Drug Release } \\
\text { After } 3 \text { hours }\end{array}$ & $83.4 \pm 1.8$ & $82.7 \pm 1.9$ & 0.84 & $82.6 \pm 1.4$ & 0.96 & $83.1 \pm 0.7 \%$ & 0.36 \\
\hline
\end{tabular}

TABLE VI - Summary of the results for Batch 2: formulated mucoadhesive mefenamic acid buccal tablet

\begin{tabular}{|c|c|c|c|c|c|c|c|}
\hline Tests & Month 0 & Month 1 & $\begin{array}{c}\text { Percent } \\
\text { Change }(\%)\end{array}$ & Month 2 & $\begin{array}{c}\text { Percent } \\
\text { Change }(\%)\end{array}$ & Month 3 & $\begin{array}{c}\text { Percent } \\
\text { Change } \\
(\%)\end{array}$ \\
\hline $\begin{array}{l}\text { Weight Variation } \\
(\mathrm{mg})\end{array}$ & $512.43 \pm 1.00$ & $514.05 \pm 0.95$ & 0.32 & $511.73 \pm 1.46$ & 0.14 & $510.41 \pm 1.71$ & 0.39 \\
\hline Hardness (kg) & $9.93 \pm 0.18$ & $9.84 \pm 0.20$ & 0.91 & $9.91 \pm 0.35$ & 0.20 & $10.65 \pm 0.28$ & 7.25 \\
\hline Thickness (mm) & $3.79 \pm 0.01$ & $3.79 \pm 0.02$ & 0 & $3.79 \pm 0.01$ & 0 & $3.79 \pm 0.01$ & 0 \\
\hline
\end{tabular}


TABLE VI - Summary of the results for Batch 2: formulated mucoadhesive mefenamic acid buccal tablet

\begin{tabular}{|c|c|c|c|c|c|c|c|}
\hline \multirow[b]{2}{*}{ Tests } & \multicolumn{6}{|c|}{ Batch 2} & \multirow{2}{*}{$\begin{array}{c}\text { Percent } \\
\text { Change } \\
(\%)\end{array}$} \\
\hline & Month 0 & Month 1 & $\begin{array}{c}\text { Percent } \\
\text { Change (\%) }\end{array}$ & Month 2 & $\begin{array}{c}\text { Percent } \\
\text { Change (\%) }\end{array}$ & Month 3 & \\
\hline Diameter (mm) & $12.056 \pm 0.002$ & $12.084 \pm 0.005$ & 0.23 & $\begin{array}{c}12.063 \pm \\
0.004\end{array}$ & 0.06 & $\begin{array}{c}12.067 \pm \\
0.005\end{array}$ & 0.09 \\
\hline Friability (\%) & $0.300 \pm 0.005$ & $0.307 \pm 0.012$ & 2.33 & $0.277 \pm 0.028$ & 7.67 & $0.367 \pm 0.019$ & 22.33 \\
\hline $\begin{array}{l}\text { Disintegration } \\
\text { (min.) }\end{array}$ & $147.70 \pm 3.41$ & $152.49 \pm 4.19$ & 3.24 & $154.23 \pm 1.66$ & 4.42 & $152.72 \pm 1.88$ & 3.40 \\
\hline $\begin{array}{l}\text { Content } \\
\text { Uniformity (\%) }\end{array}$ & $105.61 \pm 0.95$ & $105.45 \pm 0.97$ & 0.15 & $100.77 \pm 0.53$ & 4.58 & $102.48 \pm 0.76$ & 2.96 \\
\hline $\begin{array}{l}\text { Moisture } \\
\text { absorption (\%) }\end{array}$ & $15.27 \pm 0.75$ & $14.79 \pm 0.58$ & 3.14 & $15.36 \pm 0.43$ & 0.59 & $15.35 \pm 0.18$ & 0.52 \\
\hline Surface $\mathrm{pH}$ & $6.98 \pm 0.08$ & $6.80 \pm 0.07$ & 2.58 & $6.86 \pm 0.11$ & 1.72 & $6.98 \pm 0.05$ & 0.00 \\
\hline $\begin{array}{l}\text { Swelling (\%) } \\
\text { after } 3 \text { hours }\end{array}$ & $54.03 \pm 0.50$ & $58.14 \pm 0.73$ & 7.61 & $55.02 \pm 0.80$ & 1.83 & $54.94 \pm 0.74$ & 1.68 \\
\hline $\begin{array}{l}\text { Mucoadhesive } \\
\text { Strength }\end{array}$ & $0.200 \pm 0.002$ & $0.199 \pm 0.003$ & 0.50 & $0.198 \pm 0.001$ & 1.00 & $0.198 \pm 0.002$ & 1.00 \\
\hline $\begin{array}{l}\text { Residence } \\
\text { Time (min.) }\end{array}$ & $13.58 \pm 0.54$ & $12.77 \pm 0.34$ & 5.96 & $13.37 \pm 0.31$ & 1.55 & $13.42 \pm 0.26$ & 1.18 \\
\hline $\begin{array}{l}\text { Drug Release } \\
\text { After } 3 \text { hours }\end{array}$ & $80.7 \pm 0.1$ & $80.8 \pm 0.9$ & 0.12 & $81.0 \pm 0.8$ & 0.37 & $80.8 \pm 0.1$ & 0.12 \\
\hline
\end{tabular}

Both batch 1 and batch 2 conform to the acceptable range for quality control and in vitro tests. Even after 3 months of stability test at $40{ }^{\circ} \mathrm{C} / 75 \% \mathrm{RH}$, the mucoadhesive mefenamic acid buccal tablet are still within the acceptable range with no significant difference from the baseline. The authors suggest doing long term stability studies.

\section{ACKNOWLEDGMENT}

The authors are thankful to the Research Center for the Natural and Applied Sciences, Manila, Philippines; Pharmatechnica Laboratories Inc., Bulacan, Philippines; and Centro Escolar University, Makati, Philippines for the use of the laboratory facilities.

\section{REFERENCES}

Albreiki HM, Kumar S, Khan SA. In-vitro bioavailability and pharmaceutical evaluation of five brands of mefenamic acid tablets marketed in Oman. Adv J Pharm Life Sci Res. 2013;1(1):1-6.

Chaudhari S, Harsulkar, A. Design and in-vitro evaluation of mucoadhesive buccal tablets of carvedilol. Int J PharmTech Res. 2012;4(4):1827-1833. 
Chinna RP, Chaitanya KSC, Madhusudan RY. A review on bioadhesive buccal drug delivery systems: current status of formulation and evaluation methods.J Pharm Sci. 2011;19(6):385-403.

Choi H, Kim C. Development of omeprazole buccal adhesive tablets with stability enhancement in human saliva. J Control Release. 2000;68(3):397-404.

Cunha J. Mefenamic acid side effects center [Internet]. California: RxList; 2016 [updated 2016 May 25; cited 2016 Oct 31]. Available from http://www.rxlist.com/mefenamicacid-side-effects-drug-center.htm.

Fatima S, Panda N, Reddy AV, Fatima S. Buccal mucoadhesive tablets of sumatriptan succinate for treatment of sustainable migraine: design, formulation and in vitro evaluation. Int $\mathrm{J}$ Pharm Res. 2015;4(30):114-126.

Gilhotra R, Ikram M, Srivastava S, Gilhotra N. A clinical perspective on mucoadhesive buccal drug delivery systems. J Biomed Res. 2014;28(2):81-97.

Hassam N, Khar RK, Ali M, Ali J. Development and evaluation of buccal bioadhesive tablet of an anti-emetic agent ondansetron. AAPS PharmSciTech. 2009;10(4):1085-1092.

Ikeuchi-Takahashi Y, Sasatsu M, Onishi H. Evaluation of matrix type mucoadhesive tablets containing indomethacin for buccal application. Int J Pharm. 2013;453(2):454- 461.

Ito A, Konnerth C, Schmidt J, Peukert W. Effect of polymer species and concentration on the production of mefenamic acid nanoparticles by media milling. Eur J Pharm Biopharm. 2016;98:98-107.

Kasture PV, Gokhale SB, Parakh SR, Hasan SA. Practical Pharmaceutics-I. 16 ${ }^{\text {th }}$ ed. Shivaji Nagar: Nirali Prakashan. 2008.

Le J. Drug Administration [Internet]. Kenilworth NJ USA: Merck Sharp \& Dohme Corp; 2016 [cited 2016 Nov 8]. Available from: http:/www.msdmanuals.com/home/drugs/ administration-and-kinetics-of-drugs/drug-administration.

Lodhi M, Dubey A, Narayan R, Prabhu P, Priya S. Formulation and evaluation of buccal film of Ivabradine hydrochloride for the treatment of stable angina pectoris. Int J Pharm Investig. $2013 ; 3(1): 47-53$.

Padsala K, Desai K, Swamy SMV. Formulation, evaluation and optimization of mucoadhesive buccal tablet of simvastatin. Pharma Sci Monitor. 2014;5(2):55-79.
Prasad V, Senthil A, Mahalaxmi D, Chinna Reddy P, Mohideen S. Development and evaluation of mucoadhesive buccal tablets of venlafaxine $\mathrm{HCl}$. Int $\mathrm{J}$ Biol Pharm Res. 2010;1(2):100-107.

Raghavendra Rao NG, Shravani B, Reddy MS. Overview on buccal drug delivery systems. J Pharm Sci Res. 2013;5(4): 80-88.

Remington J, Beringer P. Remington: the science and practice of pharmacy. 21st ed. Philadelphia: Lippincott Williams \& Wilkins; 2006.

Russo E, Selmin F, Baldassari S, Parodi B. A focus on mucoadhesive polymers and their application in buccal dosage forms. J Drug Deliv Sci Tec. 2016;32(Part B):113-125.

Salamat-Miller N, Chittchang M, Johnston T. The use of mucoadhesive polymers in buccal drug delivery. Adv Drug Deliv Rev. 2005;57(11):1666-1691.

Semalty M, Semalty A, Kumar G. Formulation and characterization of mucoadhesive buccal films of glipizide. Indian J Pharm Sci. 2008;70(1):43-48.

Shepherd M. Administration of drugs: oral route. Nursing Times. 2011;107(32):18.

Sunitha M, Padma A, Balaji B, Ravi Krishna V, Vamshi Krishna M. Formulation and in vitro evaluation of buccal mucoadhesive tablets of chloropheneramine maleate. Int $\mathrm{J}$ Pharm Chem Biol Sci. 2014;4(3):774-784.

Velmurugan S, Srinivas P. Formulation and in vitro evaluation of losartan potassium mucoadhesive buccal tablets. Asian J Pharm Clin Res. 2013;6(3):125-130.

Vikram A, Firoz S, Kishore D, Chandra Mouli Y, Venkataramudu T. Formulation and evaluation of mefenamic acid tablets by using modified starch. Asian J Pharm Sci Tec. 2012;2(2):46-53.

Yadav Deepak R, Ayyappan T, Shanmugam S, Sundaramoorthy K, Vetrichelvan T. Development and in-vitro evaluation of buccoadhesive metoclopramide hydrochloride tablet formulations. Int J PharmTech Res. 2011;3(1):516-525.

Received for publication on $20^{\text {th }}$ July 2018 Accepted for publication on $17^{\text {th }}$ December 2018 